\title{
INTERAKSI BAP DAN NAA TERHADAP PERTUMBUHAN EKSPLAN ANGGREK VANDA SECARA IN-VITRO
}

\section{Interaction of BAP and NAA on Explant Growth of Vanda Orchid In-vitro}

\author{
Selvia Sutriana, Hasan Basri Jumin dan Mardaleni \\ Fakultas Pertanian Universitas Islam Riau Jl. Kaharuddin Nasution No.113 Pekanbaru 28284 \\ Email: selviasutriana@yamil.com,hb_jumin@yahoo.com, mardalenimuslim@ymail.com \\ Telp: 0761-674681; Fax: 0761-674681 \\ [Diterima Nopember 2013, Disetujui Maret 2014]
}

\begin{abstract}
This research aims to obtain the combination of BAP and NAA concentration which give the best effect on explant growth of Vanda orchid in-vitro. The research was conducted at the biotechnology laboratory Faculty of Agriculture Riau Islamic University Pekanbaru from August to December 2013. The completely randomized design with two factorials (BAP and NAA) was used. The observed parameters included percentage of shoot growing, shoot age, shoot height, shoot number and abnormal embryo somatic. Data were analysed using statistics and BNJ Test at the 5\% significance level. The result showed that,interactionally,BAP and NAA applications had a significant effect on height plant with the best concentration without BAP and $1.0 \mathrm{ppm}$ NAA. Individually, the application of BAP effected significantly on percentage of shoot growing, shoot growth, shoot height and shoot number with the best concentration without BAP and 0.1 BAP. Furthermore, the application of NAA influenced significantly on percentage of shoot growing, shoot age, shoot height and shoot number with the best concentration of $1.0 \mathrm{ppm}$ NNA.
\end{abstract}

Keywords: BAP, NAA, Explant growth, Vanda orchd, In-vitro

\section{ABSTRAK}

Tujuan penelitian ini untuk mendapatkan kombinasi konsentrasi BAP dan NAA yang memberikan pengaruh terbaik pada eksplan anggrek vanda secara in-vitro. Penelitian dilaksanakan di Laboratorium Bioteknologi Tanaman Fakultas Pertanian UIR Pekanbaru, selama empat bulan dimulai dari bulan Agustus sampai Desember 2013. Rancangan yang digunakan dalam penelitian ini adalah Rancangan Acak Lengkap (RAL) secara faktorial yang terdiri dari dua faktor (BAP dan NAA). Parameter yang diamati: persentase tumbuh tunas, umur bertunas, tinggi tunas, jumlah tunas dan abnormal embriosomatik. Data pengamatan dianalisa secara statistik dan uji lanjut BNJ taraf 5\%. Hasil penelitian secara interaksi pemberian BAP dan NAA berpengaruh terhadap tinggi tunas dengan konsentrasi terbaik tanpa BAP dan NAA $1.0 \mathrm{ppm}$. Secara tunggal pemberian BAP berpengaruh terhadap persentase tumbuh tunas, umur bertunas, tinggi tunas dan jumlah tunas, dengan konsentrasi terbaik tanpa BAP dan BAP $0.1 \mathrm{ppm}$. Pemberian NAA secara tunggal berpengaruh terhadap persentase tumbuh tunas, umur bertunas, tinggi tunas dan jumlah tunas, dengan konsentrasi terbaik NAA $1.0 \mathrm{ppm}$

Kata Kunci:BAP, NAA, Pertumbuhan eksplan anggrek,Anggrek vanda, In-vitro.

\section{PENDAHULUAN}

Anggrek merupakan salah satu tanaman hias yang bernilai estetika tinggi, banyak diminati dan memiliki arti penting dalam perdagangan bunga. Hal ini disebabkan karena bunganya yang indah dengan warna yang sangat menarik, serta anggrek juga dapat dijadikan sebagai tanaman pot maupun tanaman bunga potong atau elemen taman. Salah satu jenis diantaranya adalah anggrek vanda (Gunawan, 2007). Diperkirakan kekayaan variasi warna dan bentuk yang dimiliki anggrek vanda menyebabkan anggrek ini diklasifikasikan menjadi 40 species, sekitar 20 species berada di kepulauan Indonesia yang meyebar di hutanhutan tropis di Pulau Jawa, Bali, Sumatra, 
Kalimantan, Maluku dan Papua (Anonim, 2013)

Berdasarkan data dari Badan Pusat Statistik, produksi tanaman hias di Indonesia mengalami peningkatan yang cukup signifikan dari tahun 1997 sampai tahun 2008. Peningkatan yang sangat terlihat yaitu pada tanaman anggrek dan krisan. Pada tahun 1997 produksi anggrek sebesar 6.502.669 tangkai, tahun 2008 meningkat menjadi 15.309.964 tangkai dan tahun 2012 produksi anggrek menurun menjadi 14.948.699 tangkai. Sedangkan untuk Provinsi Riau produksi tanaman hias anggrek pada tahun 2008 adalah 80.481, tahun 2012 mengalami penurunan produksi yang signifikan yaitu 9.860 tangkai (Badan Pusat Statistik, 2012)

Anggrek vanda adalah anggrek monopodial dengan dominasi tunas apical sangat kuat pada pertumbuhannya (Kisor dan Devi, 2009). Perbanyakkan vegetatif anggrek vanda dilakukan dengan cara setek untuk menginduksi tunas aksiler dan cara yang dilakukan ini lambat dan perbanyakannya terbatas. Sehingga diperlukan cara yang tepat untuk menghasilkan bibit/anakan anggrek vanda dalam jumlah banyak. Salah satu cara yaitu dengan kultur jaringan tanaman.

Teknik kultur jaringan sebenarnya sangat sederhana yaitu suatu sel atau irisan jaringan tanaman yang disebut eksplan secara aseptik diletakkan dan dipelihara dalam medium padat atau cair yang cocok dalam keadaan steril. Selain itu, teknik ini dicirikan oleh penggunaan media kultur buatan dengan kandungan nutrisi lengkap dan ZPT (zat pengatur tumbuh), serta kondisi ruang kultur yang suhu dan pencahayaannya terkontrol (Yusnita,2003).

Media dasar yang digunakan adalah Murashige dan Skoog (MS) yang dicampur dengan arang aktif yang dapat menyerap senyawa fenol yang keluar dari jaringan tanaman yang terluka pada saat inisiasi. Kemudian, respon eksplan dapat ditingkatkan dengan menambahkan zat pengatur tumbuh pada media tanam eksplan. Dari golongan zat pengatur tumbuh tersebut, yang sangat penting dalam kultur jaringan adalah sitokinin dan auksin (Gunawan, 1988). Interaksi auksin dan sitokinin pada perbandingan tertentu mendorong terjadinya pertumbuhan dan diferensiasi sel-sel pada eksplan.

Sitokinin adalah salah satu zat pengatur tumbuh yang ditemukan pada tanaman. Zat pengatur tumbuh ini mempunyai peranan dalam proses pembelahan sel (cell division).BAP merupakan sitokinin turunan adenine yang paling aktif dalam proses pembelahan sel dan memacu pertumbuhan tunas. Auksin berfungsi untuk perpanjangan sel dan pembesaran jaringan, pembelahan sel, pembentukan akar adventif dan menghambat pembentukan tunas aksilar dan adventif. Jenis auksin yang digunakan dalam kultur jaringan adalah NAA. Senyawa NAA adalah auksin alami pada tumbuhan yang disintetis dari tritopan diprimordial daun, daun muda dan biji yang sedang berkembang.

Selain dari ZPT yang dibutuhkan dalam kultur jaringan tanaman anggrek, tingkat penyerapan oleh bahan tanaman sangat dipengaruhi oleh $\mathrm{pH}$ media itu sendiri. Untuk pertumbuhan, $\mathrm{pH}$ yang sesuai adalah $5,0-6,0$, sedangkan bila $\mathrm{pH}$ terlalu rendah atau terlalu tinggi dapat menghambat atau menghentikan pertumbuhan dan perkembangan kultur secara in -vitro serta juga perlu di perhatikan faktor lain seperti sterilisasi ruangan.

\section{METODE PENELITIAN}

Penelitian dilaksanakan di Laboratorium Bioteknologi Fakultas Pertanian Universitas Islam Riau Pekanbaru, selama 5 bulan dimulai dari bulan Agustus-Desember 2013.

Bahan-bahan yang digunakan dalam penelitian adalah eksplan Anggrek vanda yang berumur 3 bulan, Aquades steril, Alkohol 96\%, Media MS, Arang aktif, Vitamin, Agar-agar swallow, BAP, NAA, Glukosa, karet gelang, tissue, plastik tahan panas ukuran $1 \mathrm{~kg}$ dan label nama. Sedangkan alat-alat yang di gunakan dalam penelitian ini adalah laminar air flow cabinet, autoclave, timbangan analitik, Erlenmeyer, gelas ukur, gelas piala, petridish, pipet, pengaduk, pinset, scalpel, lampu spiritus, hand sprayer, pisau, $\mathrm{pH}$ meter, botol kultur, kompor gas, panci berlapis enamel untuk memasak media, tabung reaksi, gunting, rak kultur, nampan plastik, kereta dorong untuk mengangkut media atau botol kultur, alat tulis, perlengkapan pencucian.

Rancangan yang digunakan dalam penelitian ini adalah Rancangan Acak Lengkap (RAL) secara faktorial yang terdiri dari dua faktor, yaitu faktor $\mathrm{B}$ (BAP) dan faktor $\mathrm{N}$ (NAA). Faktor BAP terdiri dari 4 taraf 
perlakuan yaitu B0 (tanpa BAP), B1 (0.1 ppm), B2 (1.0 ppm), B3 (10.0 ppm) dan Faktor NAA terdiri dari 4 taraf yaitu N0 (tanpa NAA), N1 $(1.0 \mathrm{ppm}), \mathrm{N} 2(2.0 \mathrm{ppm}), \mathrm{N} 3 \quad(3.0 \mathrm{ppm})$. Sehingga terdapat 16 kombinasi perlakuan. Setiap perlakuan terdiri dari 4 botol kultur, sehingga 192 botol kultur secara keseluruhan.

Pelaksanaan penelitian meliputi persiapan bahan tanaman, persiapan tempat penelitian, sterilisasi alat, pembuatan media, pemberian perlakuan (BAP dan NAA), pemasangan label, penanaman eksplan, pemeliharaan dan parameter pengamatan (persentase tumbuh tunas, umur bertunas, jumlah tunas, tinggi tunas, dan abnormal embriosomatik (hyperhydricity).

\section{HASIL DAN PEMBAHASAN}

\section{Persentase Tumbuh Tunas}

Berdasarkan hasil analisis sidik ragam dari data hasil pengamatan parameter Persentase Tumbuh Tunas (\%), terlihat bahwa secara interaksi pemberian konsentrasi BAP dan NAA tidak berpengaruh nyata terhadap persentase tumbuh tunas. Sedangkan pemberian konsentrasi BAP dan NAA secara tunggal berpengaruh nyata terhadap persentase tumbuh tunas. Untuk lebih jelasnya mengenai hasil pengamatan persentase tumbuh tunas setelah dilakukan uji lanjut BNJ pada taraf 5\%, dapat dilihat pada Tabel berikut ini.

Pada Tabel 1 dapat dilihat bahwa secara interaksi persentase tumbuh tunas tidak berpengaruh nyata. Persentase tumbuh tunas tertinggi terdapat pada perlakuan B0N0 (tanpa pemberian BAP dan NAA), B0N1 (tanpa pemberian BAP dan NAA 1.0 ppm) dan B1N1 (BAP $0.1 \mathrm{ppm}$ dan NAA $1.0 \mathrm{ppm}$ ) dengan persentase tumbuh tunas $100 \%$. Perlakuan terendah terdapat pada perlakuan B3N3 (BAP $10.0 \mathrm{ppm}$ dan NAA $3.0 \mathrm{ppm}$ ) dengan persentase tumbuh tunas $66.67 \%$. Perlakuan B0N0, B0N1 dan B1N1 pertumbuhannya bagus karena eksplan anggrek vanda menginginkan konsentrasi BAP atau NAA yang rendah untuk pertumbuhannya, kalau konsentrasi yang diberikan lebih dari 1 ppm atau sampai 10.0 ppm maka hasil yang diperoleh tidak bagus seperti perlakuan B3N3 mengahasilkan persentase tunas terendah sampai $66.67 \%$. Perlakuan ini jelas terlihat bahwa pemberian konsentrasi BAP yang rendah atau tanpa pemberian BAP memberikan hasil terbaik jika di interaksikan dengan pemberian konsentrasi NAA rendah atau tanpa pemberian NAA.

Tabel 1. Rerata Persentase Tumbuh Tunas Eksplan Anggrek Vanda dengan Konsentrasi BAP dan Konsentrasi NAA $(\%)$

\begin{tabular}{|c|c|c|c|c|c|}
\hline \multirow{2}{*}{$\begin{array}{c}\text { Konsentrasi BAP } \\
(\mathrm{ppm})\end{array}$} & \multicolumn{4}{|c|}{ Konsentrasi NAA (ppm) } & \multirow[b]{2}{*}{ Rerata } \\
\hline & N0 (0.0) & $\mathrm{N} 1(1.0)$ & $\mathrm{N} 2(2.0)$ & $\mathrm{N} 3(3.0)$ & \\
\hline B0 $\quad(0.0)$ & 100.00 & 100.00 & 86.67 & 86.67 & 93.33 a \\
\hline B1 (0.1) & 90.00 & 100.00 & 93.33 & 86.67 & $92.50 \mathrm{a}$ \\
\hline B2 (1.0) & 76.67 & 80.00 & 83.33 & 73.33 & $78.33 \mathrm{~b}$ \\
\hline B3 (10.0) & 73.33 & 76.67 & 70.00 & 66.67 & $71.67 \mathrm{c}$ \\
\hline Rerata & $85.00 \mathrm{~b}$ & 89.17 a & 83.33 b & $78.33 \mathrm{c}$ & 83.96 \\
\hline
\end{tabular}

Angka-angka pada baris dan kolom yang diikuti oleh huruf kecil yang sama tidak berbeda nyata menurut Uji lanjut BNJ pada taraf $5 \%$.

Tabel 2. Rerata Umur Bertunas Eksplan Anggrek Vanda dengan Perlakuan Konsentrasi BAP dan Konsentrasi NAA $(\%)$

\begin{tabular}{|c|c|c|c|c|c|}
\hline \multirow{2}{*}{$\begin{array}{l}\text { Konsentrasi BAP } \\
\quad(\mathrm{ppm})\end{array}$} & \multicolumn{4}{|c|}{ Konsentrasi NAA (ppm) } & \multirow{2}{*}{ Rerata } \\
\hline & N0 (0.0) & $\mathrm{N} 1(1.0)$ & $\mathrm{N} 2(2.0)$ & $\mathrm{N} 3(3.0)$ & \\
\hline $\begin{array}{ll}\text { B0 } & (0.0)\end{array}$ & 15.67 & 14.33 & 19.00 & 20.00 & $17.25 \quad b$ \\
\hline $\mathrm{B} 1 \quad(0.1)$ & 17.33 & 15.00 & 16.67 & 18.00 & 16.75 a \\
\hline B2 (1.0) & 21.67 & 20.33 & 21.67 & 22.33 & $21.50 \mathrm{c}$ \\
\hline B3 (10.0) & 21.67 & 21.00 & 22.67 & 23.00 & $22.08 \mathrm{~d}$ \\
\hline Rerata & 19.08 b & $17.66 \mathrm{a}$ & 20.00 c & $20.83 \mathrm{~d}$ & 19.39 \\
\hline
\end{tabular}

$\mathrm{KK}=6.60 \% \quad$ BNJ B \& N $=0.41$

Angka-angka pada baris dan kolom yang diikuti oleh huruf kecil yang sama tidak berbeda nyata menurut Uji lanjut BNJ pada taraf $5 \%$. 
Tabel 3. Rerata Tinggi Tunas Eksplan Anggrek Vanda dengan Konsentrasi BAP dan Konsentrasi $\mathrm{NAA}(\mathrm{cm})$

\begin{tabular}{|c|c|c|c|c|c|}
\hline \multirow{2}{*}{$\begin{array}{c}\text { Konsentrasi BAP } \\
(\mathrm{ppm})\end{array}$} & \multicolumn{4}{|c|}{ Konsentrasi NAA (ppm) } & \multirow{2}{*}{ Rerata } \\
\hline & N0 (0.0) & $\mathrm{N} 1(1.0)$ & $\mathrm{N} 2(2.0)$ & $\mathrm{N} 3(3.0)$ & \\
\hline $\begin{array}{ll}\text { B0 } & (0.0)\end{array}$ & $3.15 \mathrm{c}$ & $3.35 \mathrm{c}$ & $2.67 \mathrm{~g}$ & $2.53 \mathrm{~h}$ & $2.92 \mathrm{~b}$ \\
\hline $\mathrm{B} 1 \quad(0.1)$ & $2.98 \mathrm{e}$ & $3.18 \mathrm{~b}$ & $3.07 \mathrm{~d}$ & $2.83 \mathrm{f}$ & $3.01 \mathrm{a}$ \\
\hline B2 (1.0) & $2.35 \mathrm{jk}$ & $2.45 \mathrm{i}$ & $2.32 \mathrm{jkl}$ & $2.27 \mathrm{lmn}$ & $2.35 \mathrm{c}$ \\
\hline B3 (10.0) & $2.30 \mathrm{klm}$ & $2.37 \mathrm{j}$ & 2.22 no & $2.17 \quad \mathrm{o}$ & $2.26 \mathrm{~d}$ \\
\hline Rerata & $2.69 \mathrm{~b}$ & $2.84 \mathrm{a}$ & $2.57 \mathrm{c}$ & $2.45 \mathrm{~d}$ & $\underline{2.63}$ \\
\hline
\end{tabular}

Angka-angka pada baris dan kolom yang diikuti oleh huruf kecil yang sama tidak berbeda nyata menurut Uji lanjut BNJ pada taraf $5 \%$.

Pemberian konsentrasi BAP secara tunggal berpengaruh nyata, dimana $\mathrm{B} 0$ (tanpa BAP) memberikan hasil terbaik dengan persentase tumbuh tunas $93.33 \%$, diikuti oleh B1 (0.1 ppm) dengan persentase hidup eksplan 92.50\%, B2 (1.0 ppm) dengan persentase hidup eksplan 78.33 dan B3 (10.0 ppm) dengan persentase tumbuh tunas terendah yaitu $71.67 \%$. Hal ini berarti tanpa pemberian BAP pun eksplan anggrek vanda dapat tumbuh dengan baik dibandingkan dengan pemberian BAP sampai 10.0 ppm yang hasilnya tidak memuaskan.

Untuk konsentrasi NAA secara tunggal juga berpengaruh nyata, dimana N1 (1.0 ppm) memberikan hasil terbaik dengan persentase hidup eksplan $89.17 \%$, diikuti oleh N0 (tanpa pemberian konsentrasi NAA) dengan persentase tumbuh tunas $85.00 \%$, N2 (2.0 ppm) dengan persentase tumbuh tunas $83.33 \%$ dan terendah adalah N3 (3.0 ppm) dengan persentase hidup eksplan $78.33 \%$.

\section{Umur Bertunas}

Berdasarkan hasil analisis sidik ragam dari data hasil pengamatan parameter Umur bertunas (hari), terlihat bahwa interaksi antara pemberian konsentrasi BAP dan NAA tidak berpengaruh nyata terhadap umur bertunas. Pemberian konsentrasi BAP dan NAA secara tunggal berpengaruh nyata terhadap umur bertunas. Untuk lebih jelasnya mengenai hasil pengamatan umur bertunas setelah dilakukan uji lanjut BNJ pada taraf 5\%, dapat dilihat pada Tabel berikut ini.

Pada Tabel 2 dapat dilihat bahwa secara interaksi eksplan anggrek vanda tidak berpengaruh terdapat umur bertunas. Tapi, eksplan anggrek vanda tercepat bertunas adalah perlakuan B0N1 (tanpa pemberian BAP dan NAA 1.0 ppm) dengan umur bertunas 14.33 HST dan eksplan anggrek vanda paling lambat mengeluarkan tunas adalah perlakuan B3N3 (pemberian konsentrasi BAP $10.0 \mathrm{ppm}$ dan NAA 3.0 ppm) dengan umur bertunas 23 HST.

Perlakuan B0N1 menghasilkan umur bertunas paling cepat dibandingkan yang lain karena konsentrasi yang digunakan sesuai dengan pertumbuhan tunas ekpslan anggrek vanda. Ini sesuai dengan pernyataan Sutriana (2012) bahwa umur muncul tunas tercepat umur 16 HST dengan pemberian konsentrasi IAA 0.1 ppm dan tanpa pemberian BAP pada tanaman anthurium gelombang cinta. Semakin cepat tunas terbentuk maka akan semakin meningkat pula nutrisi yang diserap oleh eksplan sehingga akan mempercepat pembentukan eksplan membentuk individu baru, karena semua eksplan masih di dalam botol yang merupakan sumber nutrisi adalah yang terdapat pada media agar tersebut. Sehingga nutrisi yang tersedia merupakan faktor utama dalam menunjang perkembangan eksplan untuk membentuk tanaman baru.

Secara tunggal pemberian konsentrasi BAP memberikan pengaruh terhadap umur bertunas anggrek vanda. Dimana B1 (0.1 ppm) muncul tunas tercepat pada umur 16.75 HST, diikuti oleh B0 (tanpa BAP) umur muncul tunas 17.25 HST, B2 (1.0 ppm) umur muncul tunas 21.50 HST dan umur muncul tunas terlama adalah B3 (10.0 ppm) yaitu 22.08 HST. Zulkarnain (2009) menyatakan bahwa sangat sulit untuk menerapkan teknik kultur jaringan dalam perbanyakan tanaman tanpa melibatkan zat pengatur tumbuh terutama golongan Sitokinin yang fungsinya lebih ke inisiasi tunas dan zat pengatur tumbuh yang diberikan harus sesuai dengan konsentrasi yang dianjurkan agar 
Tabel 4. Rerata Jumlah Tunas Eksplan Anggrek Vanda dengan Perlakuan Konsentrasi BAP dan Konsentrasi NAA(helai)

\begin{tabular}{|c|c|c|c|c|c|}
\hline \multirow{2}{*}{$\begin{array}{l}\text { Konsentrasi BAP } \\
(\mathrm{ppm})\end{array}$} & \multicolumn{4}{|c|}{ Konsentrasi NAA (ppm) } & \multirow{2}{*}{ Rerata } \\
\hline & N0 (0.0) & $\mathrm{N} 1(1.0)$ & $\mathrm{N} 2(2.0)$ & $\mathrm{N} 3(3.0)$ & \\
\hline $\begin{array}{ll}\text { B0 } & (0.0)\end{array}$ & 6.33 & 7.33 & 6.67 & 6.00 & $6.58 \mathrm{a}$ \\
\hline B1 $(0.1)$ & 5.33 & 6.17 & 6.33 & 5.67 & $5.87 \mathrm{~b}$ \\
\hline B2 (1.0) & 5.17 & 6.00 & 5.83 & 5.67 & $5.67 \mathrm{c}$ \\
\hline B3 (10.0) & 5.00 & 5.67 & 4.83 & 4.67 & $5.04 \mathrm{~d}$ \\
\hline Rerata & $5.46 \mathrm{c}$ & $6.29 \mathrm{a}$ & $5.91 \mathrm{~b}$ & $5.50 \mathrm{c}$ & $\underline{\mathbf{5 . 7 9}}$ \\
\hline $\mathrm{KK}=7.33 \%$ & $\mathrm{~N}=0.13$ & & & & \\
\hline
\end{tabular}

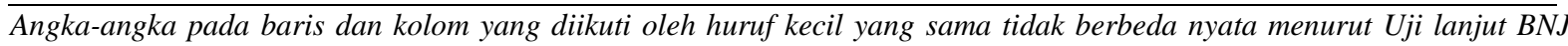
pada taraf $5 \%$.

tidak menghambat pertumbuhan tunas. Tapi dalam penelitian ini dapat dibuktikan bahwa tanpa pemberian BAP dan pemberian BAP dalam konsentrasi rendah telah mampu mempercepat pertumbuhan tunas anggrek vanda dibandingkan konsentrasi yang tinggi.

Sedangkan pemberian konsentrasi NAA secara tunggal juga memberikan pengaruh terhadap umur muncul tunas anggrek vanda. Dimana umur muncul tunas tercepat pada perlakuan N1 (1.0 ppm) yaitu 17.66 HST, diikuti N0 (tanpa NAA) dengan umur bertunas 19.08 HST, N2 (2.0 ppm) dengan umur muncul tunas 20.00 HST dan umur bertunas terlama N3 $(3.0$ ppm) yaitu 20.83 HST.Cepatnya umur bertunas pada NAA konsentrasi rendah (1.0 ppm) karena fungsi NAA lebih ke pembesaran dan pembentukan akar. Jika konsentrasi yang diberikan tinggi maka akan menghambat umur bertunas anggrek vanda dan fitohormon yang terdapat dalam eksplan masih tersedia untuk merangsang aktifitas pembelahan dan pembesaran sel serta peranan unsur hara dalam media MS juga mempengaruhi munculnya tunas.

\section{Tinggi Tunas}

Berdasarkan hasil analisis sidik ragam dari data hasil pengamatan parameter tinggi tunas $(\mathrm{cm})$, terlihat bahwa interaksi antara pemberian konsentrasi BAP dan konsentrasi NAA tidak berpengaruh nyata terhadap tinggi tunas. Pemberian konsentrasi BAP dan konsentrasu NAA secara tunggal berpengaruh nyata terhadap tinggi tunas. Untuk lebih jelasnya mengenai hasil pengamatan tinggi tunas setelah dilakukan uji lanjut BNJ pada taraf 5\%, dapat dilihat pada Tabel berikut ini.
Dari Tabel 3 dapat dilihat secara interaksi pemberian konsentrasi BAP dan NAA memberikan pengaruh terhadap tinggi tunas. Perlakuan terbaik adalah B0N1 (tanpa pemberian BAP dan NAA $1.0 \mathrm{ppm}$ ) dengan tinggi tunas $3.35 \mathrm{~cm}$ dan tinggi tunas terendah terdapat pada perlakuan B3N3 (BAP 10.0 ppm dan NAA $3.0 \mathrm{ppm}$ ) yaitu $2.17 \mathrm{~cm}$. Hal ini jelas terlihat bahwa eksplan anggrek vanda membutuhkan konsentrasi BAP dan NAA yang rendah untuk meningkatkan pertumbuhan tunasnya, sedangkan kalau konsentrasinya tinggi atau berlebihan maka akan memperlambat pertumbuhan tunasnya.

Menurut Gunawan (1988), berhasilnya pertumbuhan tunas selain ditentukan oleh jenis dan kadar hormon pertumbuhan juga bergantung pada sumber jaringan serta kadar medium hara. Unsur hara yang diserap tersedia bagi tanaman mendorong aktifitas metabolisme dalam jaringan tanaman tersebut dan menyebabkan sel-sel tanaman akan membelah. Tingginya respon jaringan untuk tumbuh, tergantung pada kemampuan auksin dan sitokinin yang ditambahkan kedalam media untuk merubah ZPT endogen dalam sel.

Secara tunggal pemberian BAP memberikan pengaruh terhadap tinggi tunas. Dimana $\mathrm{B} 1(0.1 \mathrm{ppm})$ memperoleh tunas tertinggi yaitu $3.01 \mathrm{~cm}$, diikuti oleh B0 (tanpa pemberian BAP) dengan tinggi tunas $2.92 \mathrm{~cm}, \mathrm{~B} 2(1.0 \mathrm{ppm})$ dengan tinggi tunas $2.35 \mathrm{~cm}$ dan terendah tinggi tunas adalah B3 $(10.0 \mathrm{ppm})$ yaitu $2.26 \mathrm{~cm}$. Hal ini dapat dilihat bahwa untuk pertumbuhan tinggi tunas eksplan anggrek vanda yang baik konsentrasi BAP yang dibutuhkan rendah. Jika konsentrasi yang diberikan tinggi maka akan menghambat pertumbuhan tunas.

Pemberian NAA secara tunggal juga memberikan pengaruh terhadap tinggi tunas. 
Dimana N1(1.0 ppm) menghasilkan tinggi tunas terbaik yaitu $2.84 \mathrm{~cm}$ diikuti oleh N0 (tanpa pemberian NAA) dengan tinggi tunas $2.69 \mathrm{~cm}$, $\mathrm{N} 2(2.0 \mathrm{ppm})$ dengan tinggi tunas $2.57 \mathrm{~cm}$ dan $\mathrm{N} 3(3.0 \mathrm{ppm})$ memperoleh tinggi tunas terendah yaitu $2.45 \mathrm{~cm}$. Hal ini dapat dilihat bahwa untuk pertumbuhan tinggi tunas anggrek vanda yang baik membutuhkan konsentrasi NAA yang rendah karena NAA fungsinya lebih bersifat mempengaruhi pembentukan dan perpanjangan akar tanaman. Tanpa diberi NAA pun tinggi tunas anggrek vanda bagus pertumbuhannya.

\section{Jumlah Tunas}

Berdasarkan hasil analisis sidik ragam dari data hasil pengamatan parameter jumlah tunas (buah), terlihat bahwa interaksi antara pemberian konsentrasi BAP dan konsentrasitidak berpengaruh nyata terhadap jumlah tunas. Pemberian konsentrasi BAPdan konsentrasi NAA secara tunggal berpengaruh nyata terhadap jumlah tunas. Untuk lebih jelasnya mengenai hasil pengamatan jumlah tunas setelah dilakukan uji lanjut BNJ pada taraf 5\%, dapat dilihat pada Tabel berikut ini.

Pada Tabel 4 dapat dilihat bahwa secara interaksi pemberian konsentrasi BAP dan konsentrasi NAA tidak memberikan pengaruh terhadap jumlah tunas eksplan anggrek vanda. Perlakuan B0N1 (tanpa BAP dan NAA 1.0 ppm) menghasilkan jumlah tunas terbanyak yaitu 7.33 helai dibandingkan perlakuan lain dan jumlah tunas terendah terdapat pada perlakuan B3N3.

Hal ini diduga terjadi sitokinin endogen yang terdapat pada jaringan eksplan yang sudah cukup, sehingga dengan penambahan sitokinin eksogen kedalam media justru tidak menguntungkan bagi pertumbuhan eksplan.Tanpa penambahan ZPT eksogen BAP telah mampu menginduksi pembentukan tunas baru karena kandungan sitokinin endogen yang ada dalam eksplan anggrek vanda cukup tinggi. Menurut Pierik (1984) sitokinin berperan dalam memacu pertumbuhan dan perkembangan tanaman, khususnya menginduksi tunas adventif.

Pemberian BAP secara tunggal memberikan pengaruh terhadap jumlah tunas, dimana B0 (tanpa BAP) jumlah tunas 6.58 helai, diikuti oleh B1 (0.1 ppm) dengan jumlah tunas 5.87 helai, B2 (1.0 ppm) dengan jumlah tunas 5.67 helai dan jumlah tunas terendah adalah B3 (10.0 ppm) yaitu 5.04 helai. Terjadinya peningkatan jumlah tunas pada perlakuan B0 karena ZPT eksogen BAP telah mampu menginduksi pembentukan tunas baru karena kandungan sitokinin endogen yang ada dalam eksplan anggrek vanda cukup tinggi. Sedangkan kelebihan BAP atau konsentrasi tinggi dapat menghambat jumlah tunas eksplan anggrek vanda.

Pemberian NAA secara tunggal juga memberikan pengaruh terhadap eksplan anggrek vanda. Dimana N1 (1.0 ppm) dengan jumlah tunas 6.29 helai, diikuti oleh $\mathrm{N} 2(2.0 \mathrm{ppm})$ dengan jumlah tunas 5.91 helai, N3 (3.0 ppm) dengan jumlah tunas 5.50 helai dan terendah adalah perlakuan N0 (tanpa NAA) dengan jumlah tunas 5.46 hel ai.Tingginya respon jumlah tunas pada perlakuan N1 karena konsentrasi yang diberikan sesuai dengan yang dibutuhkan eksplan anggrek vanda. Sedangkan rendahnya respon yang ditunjukkan oleh N0 dalam jumlah tunas karena tidak adanya nutrisi hara yang diserap oleh eksplan sehingga pertumbuhannya tidak berkembang dengan baik.

\section{Abnormal Embriosomatik (Hyperhyddricity)}

Pada penelitian ini terdapat beberapa eksplan yang abnormal atau tidak tumbuh seperti eksplan yang lainnya, yaitu perlakuan B3N2 dan B3N3. Pada perlakuan ini terlihat secara visual anggrek vanda yang tidak tumbuh atau tumbuh tapi layu dan pucat karena kekurangan nutrisi. Pada awal tanam terlihat eksplan berwana hijau namun setelah 4 minggu setelah tanam terlihat eksplan layu hijau kecoklatan dan umur 6 minggu berwarna putih dan akhirnya mati. Hal ini dikarenakan karena eksplan kekurangan nutrisi atau mungkin kelebihan konsentrasi BAP dan NAA yang diberikan. Sehingga eksplan anggrek vanda ini hanya bertahan hidup sampai umur 6 minggu.

Abnormal Embriosomatik (Hyperhydricity) adalah kerusakan fisiologis yang mengakibatkan hidrasi berlebihan, lignifikasi rendah, gangguan fungsi stomata dan mengurangi kekuatan kultur jaringan tanaman yang dihasilkan. Resikonya regenerasi pertumbuhan tanaman terhambat tanpa penanganan secara intensif selama proses aklimatisasi.

Hyperhydricity juga dapat menyebabkan kebekuan tunas daun dan hilangnya dominansi 
apikal di daun. Sedangkan menurut pendapat Cassels and Curry (2001) bahwa secara umum gejala utama dari hyperhydricity adalah ditandai dengan kekurangan klorofil dan kandungan air yang tinggi. Secara khusus, kurangnya lapisan kutikula, mengurangi jumlah selpalisade, stomata tidak teratur, dinding sel kurang berkembang dan ruang intra seluler besar dilapisan selmesofil telah digambarkan sebagai beberapa perubahan anatomi terkait dengan hyperhydricity.

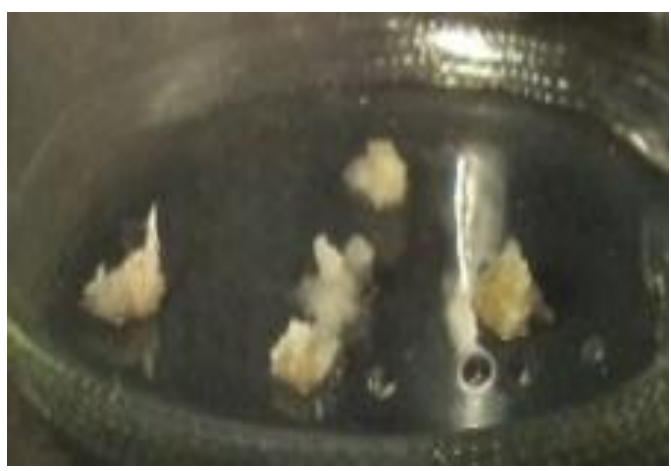

Gambar 1. Eskplan Anggrek Vanda yang Abnormal Embriosomatik pada Umur 45 HST

\section{KESIMPULAN}

Dari hasil penelitian yang telah dilakukan dapat diambil kesimpulan, bahwa:

1. Interaksi pemberian BAP dan NAA mem berikan pengaruh terhadap parameter tinggi tunas. Konsentrasi terbaik adalah B0N1 (tanpa pemberian BAP dan pemberian NAA $1.0 \mathrm{ppm})$

2. Pemberian BAP berpengaruh nyata terhadap persentase tumbuh, umur bertunas, jumlah tunas dengan konsentrasi terbaik tanpa pemberian BAP dan parameter tinggi tunas dengan konsentrasi terbaik $0.1 \mathrm{ppm}$.

3. Pemberian NAA berpengaruh nyata terha- dap persentase tumbuh tunas, umur bertunas, tinggi tunas, dan jumlah tunas. Konsentrasi terbaik adalah $1.0 \mathrm{ppm}$.

\section{DAFTAR PUSTAKA}

Anonim. 2013. Anggrek Vanda. Berita Anggrek. Onine pada: logspot.com/ 2013/04/Anggrekvanda.html. Diakses 11 September 2013

Badan Pusat Statistik. 2012. Produksi Tanaman Hias Indonesia, Jakarta.

Cassells, A and R. Curry. 2001. Oxidative Stress and Physiological, Epigenetic and Genetic Variability in Plant Tissue Culture: Implications for Micropropaga-tors and Genetic Engineers. Plant Cell Tissue and Organ Culture, 64 (2-3):145-157.

Gunawan, 2007. Budidaya Anggrek. Penebar Swadaya. Jakarta.

1988. Teknik Kultur Jaringan Tumbuhan. Laboratorium Kultur Jaringan Tanaman Pusat Antar Universitas Bioteknologi, Institut Pertanian Bogor. Bogor.

Kisor, R danH. S. Devi. 2009. Introduction of Multiple Shoots in Monopodial Orchid Hybrid Using Thidiazuron and Analysis of Their Genetic Stability, Plant. Cell. Tis. and org. Cultr, 97: 21-9

Pierik,R. L.M., H. M. Stoegmans and J.A.J. Van der Mays. 1984. Plantlet formation an callus tissue of Anthurium andreanum Lind. Sci. Hort. 2: 193-198.

Sutriana, S. 2012. Interaksi BAP (Benzil Amino Purin) dan IAA (Indole Acetat Acid) Pada Eksplan Anthurium (Anthurium sp) Dalam Kultur Jaringan Tanaman. Jurnal Dinamika Pertanian, 27(3): 131-140

Yusnita, 2003. Kultur Jaringan Cara Memperbanyak Tanaman Secara Efisien. Agromedia Pustaka, Jakarta.

Zulkarnain. 2009. Kultur Jaringan Tanaman. Bumi Aksara. Jakarta. 
